\title{
Non-communicating multiseptate gall bladder and choledochal cyst: a case report and review of publications
}

\author{
C E L Tan, E R Howard, M Driver, I M Murray-Lyon
}

\begin{abstract}
A 14 year old girl with multiseptate gall bladder and cystic dilatation of the biliary tree is presented. This is the 20th published case report of patients with multiseptate gall bladder and only the second to be associated with a choledochal cyst. The cystic spaces of the gall bladder did not communicate with the neck of the gall bladder or the rest of the biliary tree, and this unusual feature has not been previously described. A multiseptate gall bladder with a normal biliary tree commonly causes symptoms suggestive of cholecystitis, although gall stones are seldom present. Diagnosis is confirmed by an oral cholecystogram or ultrasound scan that may show the fine intraluminal septae, and these features should be looked for in patients with biliary symptoms without biliary calculi. Cholecystectomy is curative for the isolated gall bladder anomaly but hepaticojejunostomy may be necessary for an associated choledochal cyst.
\end{abstract}

(Gut 1993; 34: 853-856)
Multiseptate gall bladders are rare anomalies that were first described in 1963 by Simon and Tandon. ${ }^{1}$ Eighteen further cases (Tables I and II) have now been reported. In one there was coexistent fusiform dilatation of the extrahepatic bile ducts and a long common pancreaticobiliary channel. ${ }^{2}$ We report a second case of a multiseptate gall bladder associated with cystic dilatation of the common bile duct. No communication was found between the loculi of the gall bladder and the lumen of the rest of the biliary tract.

\section{Case report}

A 14 year old girl from Qatar presented with a one year history of intermittent pyrexia, occurring two to three times a month and often reaching up to $40^{\circ} \mathrm{C}$. This was accompanied by rigors, nausea, and some generalised abdominal discomfort, but there was no vomiting, diarrhoea, or jaundice.

At presentation she was well nourished and

TABLE I Case reports of multiseptate gall bladder (adults)

\begin{tabular}{|c|c|c|c|c|c|c|}
\hline Reports & Age (y) & Sex & Symptoms & $\begin{array}{l}\text { Duration } \\
\text { of symptoms }\end{array}$ & $\begin{array}{l}\text { Gall bladder } \\
\text { contents }\end{array}$ & Surgery \\
\hline Simon, Tandon $(1963)^{1}$ & 32 & $\mathrm{~F}$ & Upper abdominal pain $\rightarrow$ back & $7 y$ & Viscid bile & $\mathrm{C}$ \\
\hline $\operatorname{Bigg}(1964)^{21}$ & 38 & $M$ & RHC pain $\rightarrow$ scapula & 8 weeks & NR & $\mathrm{C}$ \\
\hline Sachsse et al $(1968)^{22}$ & 50 & $M$ & Upper abdominal pain & $2 y$ & - & - \\
\hline Bhagavan, et al (1970)" & 27 & $\mathbf{F}$ & RHC pain $\rightarrow$ epigastric & & Viscid bile & C \\
\hline Croce $(1973)^{7}$ & 45 & $\mathrm{~F}$ & Epigastric pain & 5 months & Several stones & C \\
\hline Codinach, et al $(1975)^{8}$ & 28 & $\mathrm{~F}$ & RHC pain $\rightarrow$ epigastric & $11 \mathrm{y}$ & One stone & C \\
\hline Shaw, et al $(1975)^{24}$ & 31 & $\mathrm{~F}$ & RHC pain $\rightarrow$ shoulder & 6 months & NR & C \\
\hline Konishi, et al $(1975)^{25}$ & 51 & $\mathrm{~F}$ & Epigastric pain & $31 \mathrm{y}$ & NR & C \\
\hline Jena, et al $(1977)^{12}$ & 28 & $\mathbf{F}$ & RHC pain $\rightarrow$ shoulder & 5 months & Green bile & C \\
\hline Okuda, et al (1979) & 37 & $\mathbf{M}$ & RHC pain & $22 \mathrm{y}$ & Brown bile & C \\
\hline Alawneh, et al (1981) & 44 & $\mathrm{~F}$ & RHC pain $\rightarrow$ back & $20 \mathrm{y}$ & Pea sized stones & C \\
\hline Toombs, et al $(1982)^{23}$ & 22 & $\mathrm{~F}$ & RHC pain & 2 days & NR & C \\
\hline Olivia, et al (1985) & 24 & $\mathrm{~F}$ & RHC pain & 4 weeks & NR & C \\
\hline \multirow[t]{2}{*}{ Lev-Toaff, et al (1987) } & 30 & $M$ & Symptom free (pancreatitis) & - & - & - \\
\hline & 23 & $\mathbf{F}$ & Symptom free & - & - & - \\
\hline Vasinrapee, et al (1990) ${ }^{6}$ & 24 & $\mathbf{M}$ & RHC pain & NR & NR & NR \\
\hline
\end{tabular}

Histopathology, King's

College Hospital,

London

M Driver

Department of

Gastroenterology,

Charing Cross Hospital,

London

I M Murray-Lyon

Correspondence to:

E R Howard, Department of

Surgery, King's College Hospital, Des.

Accepted for publication

22 September 1992
No patient had jaundice and all bile ducts were normal.

$\mathrm{RHC}=$ right upper quadrant; $\mathrm{N}=$ normal; $\mathrm{NR}=$ not reported; $\mathrm{C}=$ cholecystectomy.

TABLE II Case reports of multiseptate gall bladder (children)

\begin{tabular}{|c|c|c|c|c|c|c|}
\hline Reports & Age (y) & Sex & Symptoms & $\begin{array}{l}\text { Duration } \\
\text { of symptoms }\end{array}$ & $\begin{array}{l}\text { Gall bladder } \\
\text { contents }\end{array}$ & Surgery \\
\hline $\begin{array}{l}\text { Haslam, et al }(1966)^{13} \\
\text { Pery, et al }(1985)^{2}\end{array}$ & $\begin{array}{r}15 \\
8\end{array}$ & $\mathbf{F}$ & $\begin{array}{l}\text { RHC pain } \rightarrow \text { epigastric } \\
\text { Recurrent jaundice, bile ducts } \\
\text { dilated }\end{array}$ & $\begin{array}{l}4 y \\
4.5 y\end{array}$ & $\begin{array}{l}\text { Normal bile } \\
\text { NR }\end{array}$ & $\stackrel{\mathrm{C}}{\mathrm{C}}+\mathrm{CD}$ \\
\hline $\begin{array}{l}\text { Fremond, et al }(1989)^{15} \\
\text { Present case }\end{array}$ & $\begin{array}{l}13 \\
14\end{array}$ & $\begin{array}{l}\mathrm{F} \\
\mathrm{F}\end{array}$ & $\begin{array}{l}\text { RHC pain } \\
\text { Recurrent pyrexia, bile ducts } \\
\text { dilated }\end{array}$ & $\begin{array}{l}\text { NR } \\
1 y\end{array}$ & $\begin{array}{l}\text { NR } \\
\text { Clear mucus }\end{array}$ & $\stackrel{\mathrm{C}}{\mathrm{C}}+\mathrm{HJ}$ \\
\hline
\end{tabular}

$\mathrm{CD}=$ choledochoduodenostomy; $\mathrm{HJ}=$ hepaticojejunostomy. Other abbreviations as for Table $\mathrm{I}$. 


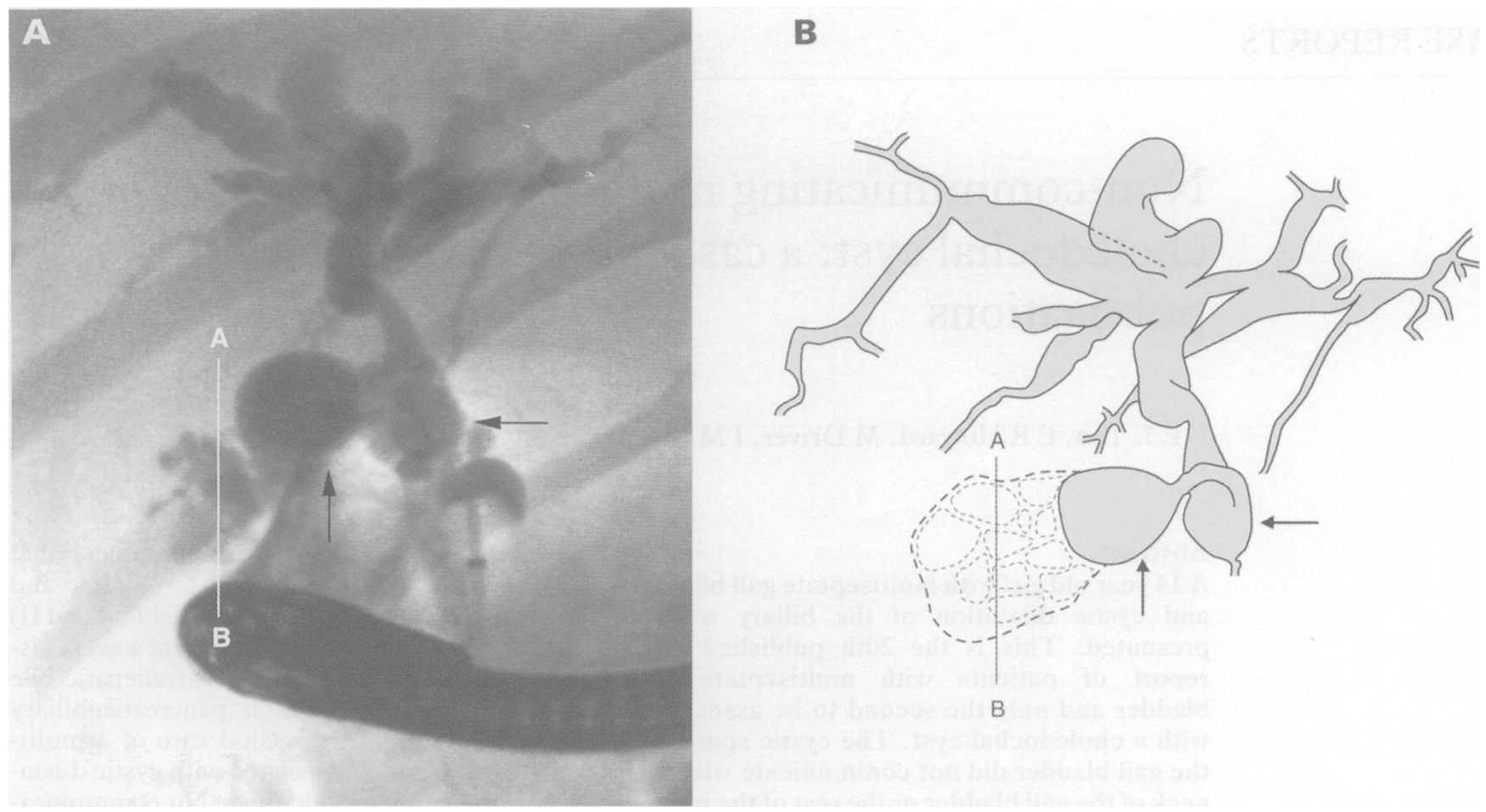

Figure 1: Endoscopic

retrograde cholangiogram $(A)$ and explanatory diagram $(B)$ in a 14 year old girl. The extrahepatic and intrahepatic ducts show generalised dilatation $(\leftarrow)$. Only the neck of the gall bladder opacifies $(\uparrow)$. The pancreatic duct is not seen. The line $A-B$ represents the plane of the histology section in Fig $2 A$. afebrile, with no signs of chronic liver disease. Her haemoglobin concentration was $9 \cdot 5 \mathrm{~g} / \mathrm{dl}$, and white cell and platelet counts were normal. Serum electrolytes were normal. Serum bilirubin concentration was $4 \mu \mathrm{mol} / /$, alkaline phosphatase activity $217 \mathrm{IU} / \mathrm{l}, \gamma$ glutamyl transpeptidase activity $226 \mathrm{IU} / \mathrm{l}$ (raised), aspartate transaminase activity $30 \mathrm{IU} / \mathrm{l}$, albumin concentration $39 \mathrm{~g} / \mathrm{dl}$, and International Normalised Ratio 1.08.

An ultrasound scan of the abdomen showed cystic dilatation of the common bile duct with some dilatation of the intrahepatic duct, and these findings were confirmed by endoscopic retrograde cholangiopancreatography (Fig $1(A))$. Surgery was recommended for treatment of the choledochal cyst that was thought to be the cause of recurrent cholangitis.

\section{FINDINGS AT OPERATION}

The body and fundus of the gall bladder were divided into cystic spaces by multiple septa. The cysts were distended with clear mucus (Fig 2), which showed a normal amylase concentration of $8 \mathrm{IU} / \mathrm{l}$. The neck of the gall bladder contained bile and did not communicate with the multiseptate body. An operative cholangiogram confirmed the findings of endoscopic retrograde cholangiopancreatography, and also showed that there was no opacification of the cystic portion of the gall bladder (Fig $1(B)$ ). Bile aspirated from the common bile duct contained high amylase activity $(800 \mathrm{IU} / \mathrm{l})$. The pancreas and liver were macroscopically normal. The multiseptate gall bladder was excised and the common bile duct was transected and removed together with the choledochal cyst. A hepaticojejunostomy was performed with a $45 \mathrm{~cm}$ Roux en Y loop of jejunum and a tru-cut biopsy of the liver was taken. The patient made an uncomplicated recovery and was discharged from hospital on the 13th day after operation. She has remained anicteric and well for one year after operation.

\section{HISTOPATHOLOGY}

The gall bladder showed an irregular lobular external appearance. Slicing showed small cystic spaces measuring up to $0.7 \mathrm{~cm}$ in diameter, some of which contained minute amounts of inspissated bile. Figure $2(A)$ shows the histological findings.

The cystically dilated bile duct measured $6 \mathrm{~cm}$ in length and up to $2 \mathrm{~cm}$ in diameter. The wall was composed of chronically inflamed collagenous fibrous tissue (Fig $2(B)$ ). The liver biopsy showed moderate expansion of the portal tracts together with some ductular proliferation and active chronic inflammation. Periductal fibrosis was present indicating ascending infection.

\section{Discussion}

A review of the 20 cases described to date shows a female preponderance (female:male $=3: 1$ ) and a mean age of 29 (range 8-51) years. Four of the patients were younger than 16 years of age. Right upper quadrant pain suggestive of biliary colic was the presenting complaint in $60 \%$, commonly with radiation to the epigastrium, right shoulder, or back. Duration of symptoms averaged 6.6 years. Jaundice was absent in all of the cases with undilated bile ducts. Of the two patients with biliary duct dilatation, the eight year old girl reported by Pery et al presented with recurrent jaundice, ${ }^{2}$ and our patient had recurrent pyrexia but remained anicteric.

Two patients did not complain of biliary symptoms and their gall bladder abnormalities were found during ultrasonography for pyelonephritis and pancreatitis. ${ }^{+}$The patient who had 

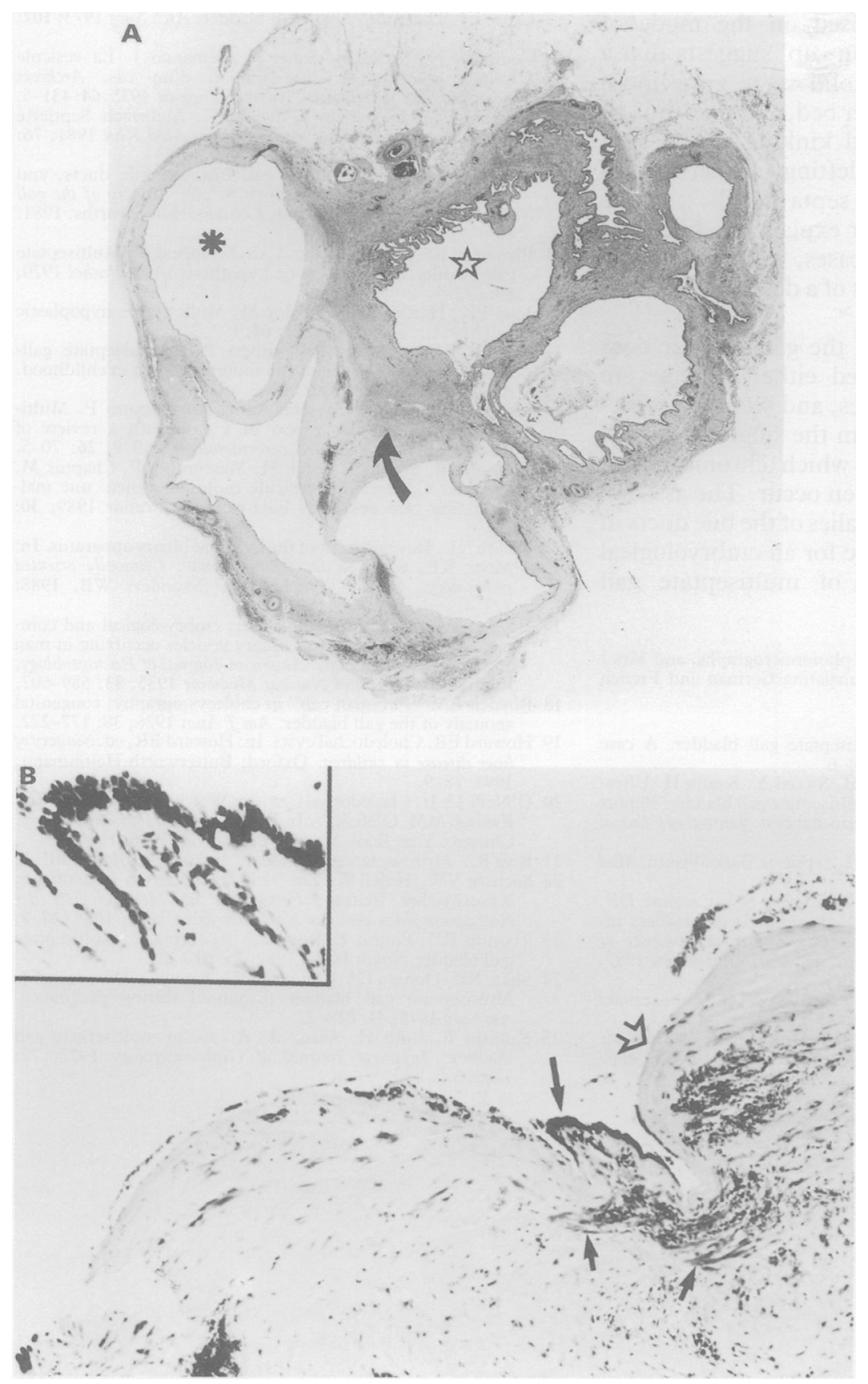

Figure 2: (A) Section through the body of the gall bladder showing cystic spaces. The walls are composed of collagenous fibrous tissue with focal acute on chronic inflammation. Some cysts are lined by hyperplastic tall columnar epithelium ( $\star$ ), others by low cuboidal epithelium $\left({ }^{\star}\right)$. Smooth muscle fibres and chronic inflammatory changes are present in the septa $(\uparrow$, haematoxylin and eosin. Originally $\times 7$ ).

(B) Section from the wall of the choledochal cyst shows the lining is predominantly of collagenous fibrous tissue without epithelium (ه). In one area of a cleft lined by cuboidal epithelium is seen $(\uparrow)$, beneath it are some smooth muscle fibres. $(\uparrow$, haematoxylin and eosin: originally $\times 7)$. Inset: high power view of the cuboidal epithelium. The apparent multilayering is due to oblique cutting (haematoxylin and eosin. Originally $\times 100$ ).

ultrasound for pancreatitis eventually died from severe haemorrhagic pancreatitis attributed to alcohol. A non-inflammed multiseptate gall bladder was found on necropsy.

Oral cholecystography was the usual examination in earlier cases, and showed thin linear radiolucent septa within the gall bladder, communicating cysts, and good contractility in six patients. Olivia et al reported the first case diagnosed with ultrasonography, ${ }^{5}$ and Lev-Toaff et al described the sonographic features of multiple, fine, non-shadowing septations that bridge the lumen of the gall bladder. ${ }^{4} \mathrm{~A}$ 'clover leaf pattern has been described in scans of the ${ }^{99 m}$ Tc diisopropylimino diacetic acid radionuclide. ${ }^{6}$

Knight stated that 'the multiseptate gall bladder is usually associated with multiple calculi. ${ }^{10}$ Only three of the 20 cases of true multiseptate disease, however, showed stones ${ }^{7-9}$ and these cases should not be confused with the commoner findings of one to three gall bladder septa that may be associated with stones in up to $22 \%$ of cases. ${ }^{3}$ Gall bladders containing one to three septa are not unusual, and were recognised in $3.8 \%$ of 2437 oral cholecystograms and intravenous cholangiograms. ${ }^{3}$

The external appearance of multiseptate gall bladders varies from normal to bosselated. They feel spongy and when cut open show a honeycomb of multiple cysts ranging from $2-16 \mathrm{~mm}$ in diameter. Small intercommunicating openings in the septa may be found. Eleven of the 17 gall bladders that were removed showed mild to moderate chronic cholecystitis. It is not easy to account for the symptoms in the condition. Acute inflammation has not been reported and a complete absence of any chronic inflammatory change was noted in six cases. ${ }^{411-15}$ Our patient did show areas of acute on chronic inflammation and mucosal ulceration but these changes may have been caused by the episodes of cholangitis that were secondary to the choledochal cyst.

Our patient was unusual in that the multiseptated fundus and body of the gall bladder had lost communication with the neck of the gall bladder and the rest of the biliary tree. This may have been an acquired phenomenon caused by the inflammation and mucosal proliferation in the gall bladder. The multiseptated portion was distended with clear mucus containing only $8 \mathrm{U} / 1$ of amylase, but the biliary duct amylase was 100 times higher, which confirmed the absence of communication between the bile duct and gall bladder. High biliary amylase concentrations in choledochal cysts are usually associated with common pancreaticobiliary channels although this was not found in our patient.

The gall bladder in early gestation is composed of three cell layers, an inner endodermal epithelium and two outer mesodermal layers that later become the tunica muscularis and the subserosa. When epithelial proliferation occurs in the second month of fetal life, the small hollow gall bladder vesicle becomes a solid tube. Vacuolisation of the solid endoderm then follows, and intraepithelial clefts coalesce to form the lumen of the gall bladder. ${ }^{16}$ It has been suggested that incomplete vacuolisation of the solid gall bladder bud is responsible for the formation of gall bladder septa. ${ }^{13}$ This does not explain the presence of the smooth muscle fibres found in the septa, as according to this theory they should be entirely endodermal in origin.

Bhagavan et al proposed that the wrinkling or infolding of the gall bladder bud found in cats and guinea pigs during the solid stage of development $^{17}$ may occur in the human fetus. ${ }^{11}$ This process draws mesoderm into the gall bladder and when subsequent vacuolisation occurs, the clefts may fail to coalesce. The remaining intraluminal endoderm and mesoderm could give rise to fibromuscular septa lined by epithelium. 
A third hypothesis based on the mode of formation of the 'Phrygian cap' suggests that a gall bladder may in its solid stage grow more rapidly than its gall bladder bed, and may thus be subjected to bending and kinking. ${ }^{18}$ The next phase of intraepithelial clefting is then incomplete, and intraluminal septa result. " These theories, however, do not explain the bile duct dilatation, found in two cases, which is usually considered to be the result of a defect in embryogenesis of the bile ducts. ${ }^{190}$

Multiseptate disease of the gall bladder does not seem to be associated either with severe inflammation or gall stones, and seems to represent a different entity from the single or double septated gall bladder in which chronic cholecystitis and gall stones often occur. The association with congenital anomalies of the bile ducts in two cases may be evidence for an embryological event in the formation of multiseptate gall bladder.

We thank Dr J G Moscoso for the photomicrographs, and Mrs I Harris and $\mathrm{Mr} \mathrm{H}$ Khawaja for translating German and French references.

1 Simon M, Tandon BN, Multiseptate gall bladder. A case report. Radiology 1963; 80: 84-6.

2 Pery M, Kaftori JK, Marvan H, Sweed Y, Kerna H. Ultrasonographic appearance of multiseptate gall bladder. Report of a case with coexisting choledochal cyst. Fournal of Clinical Ultrasound 1985; 13: 570-3.

3 Spech RJ, Hummer N, Braun H. Septierte Gallenblasen. Med Klin 1975; 70: $941-6$.

4 Lev-Toaff AS, Friedman AC, Rindsberg SN, Caroline DF, Maurer AH, Radecki PD. Multiseptate gall bladder: incidental diagnosis on sonography. American fournal of Roentgenology, Radium Therapy, and Nuclear Medicine 1987; 148: 1119-20.

5 Olivia IO, Moran MR, Sanchez FL, Alonso AG. Multi-septate gall bladder. Int Surg 1985; 70: 83-8.

6 Vasinrapee P, Linden K, Cook RE. Multiseptate gall bladder demonstrated on Tc-99m hepatobiliary imaging. Clin Nucl Med 1990; 15: 272.
7 Croce EJ. The multiseptate gall bladder. Arch Surg 1973; 107 104-5.

8 Codinach N, Sarles H, Sahel J, Alemanno J. La vesicule biliaire multiseptale: presentation d'un cas. Archives Francaises des Maladies del'A ppareil Digestif 1975;64:431-5.

9 Alawneh I Gallenblase als Ursache von Koliken. Med Klin 1981; 76: Gallenb.

$10 \mathrm{Knight} S$. Anomalies of the gall bladder, bile ducts, and arteries. In: Smith R, Sherlock S, eds. Surgery of the gall bladder and bile ducts. 2nd ed. London: Butterworths, 1981: 105.

11 Bhagavan BS, Amin PB, Land AS, Weinberg T. Multiseptate gall bladder. Embryogenetic hypothesis. Arch Pathol 1970; 89: 382-5

12 Jena PK, Hardie RA, Hobsley M. Multiseptate hypoplastic gall bladder. Brf Surg 1977; 64: 192-3.

13 Haslam RHA, Gayler BW, Ebert PA. Multiseptate gallbladder. A cause of recurrent abdominal pain in childhood. Am $\mathcal{F}$ Dis Chil 1966; 112: 600-3.

14 Okuda K, Nakajima M, Nakayama M, Nomura F. Multiseptate gall bladder: report of a case with a review of septate gall bladder: report of a case with a review of
literature. Acta Hepato-Gastroenterologica 1979; 26: 70-5.

15 Fremond B, Stasik C, Jouan H, Marcorelles P, Chapuis M, Treguier C, et al. La vesicule multicloisonnee: une malTreguier C, et al. La vesicule multicloisonnee: une malformation

16 Moore KL. Development of the liver and biliary apparatus. In Moor KL, ed. The developing human. Clinically oriented embryology. 4th ed. Philadelphia: Saunders WB, 1988 223-4.

17 Boyden EA. Accessory gallbladder; embryological and comparative study of aberrant biliary vesicles occurring in man and domestic mammals. American fournal of Roentgenology, Radium Therapy, and Nuclear Medicine 1935; 33: 589-602.

18 Boyden EA. "Phrygian cap" in cholecystography; congenita Boyden EA. "Phrygian cap" in cholecystography; congenital
anomaly of the gall bladder. Am $\mathcal{7}$ Anat 1926; 38: 177-222.

19 Howard ER. Choledochal cysts. In: Howard ER, ed. Surgery of liver disease in children. Oxford: Butterworth-Heinnmann, 1991: 78-9.

20 O'Neill JA Jr. Choledochal cyst. In: Welch KJ, Randolph JG, Ravitch MM, O’Neill JA Jr, Rowe MI, eds. Pediatric surgery. Chicago: Year Book Medical Publishers, 1986: 1056.

21 Bigg RL. Multiseptate gall bladder. Arch Surg 1964; 88: 501-2

22 Sachsse VW, Hiller W. Zur vielfach septierten Gallenblase Kasuistischer Beitrag. Fortschritte auf dem Gebiete der Roentgenstrahlen und der Nuclearmedizin 1968; 108: 547-8.

23 Toombs BD, Foucar E, Rowlands BJ, Strax R. Multiseptate gall bladder. South Med F 1982; 75: 610-2.

24 Shaw RB, Donato CA, Douglas DD, Sass JK, Montegut FJ. Multiseptate gall bladder diagnosed during pregnancy. Multiseptate gall bladder

25 Konishi F, Saito H, Asano A. A case of multiseptate gall bladder. Fapanese fournal of Gastroenterology 1975; 72: $1252-6$ 